\title{
Chromosome 1 Satellite 2
}

National Cancer Institute

\section{Source}

National Cancer Institute. Chromosome 1 Satellite 2. NCI Thesaurus. Code C128300.

A satellite DNA located in the large heterochromatin regions of chromosome 1. 